\title{
Echocardiographic diagnosis of interventricular septum defect with Eisenmenger syndrome in an adult dog - case report
}

\author{
Diagnóstico ecocardiográfico de defeito do septo interventricular \\ com agravo de síndrome de Eisenmenger em cão adulto - relato de caso \\ Thays Ribeiro Pacó ${ }^{(\mathbb{D})}$, Caroline Coelho Rocha ${ }^{(\mathbb{D})}$, Zacarias Jacinto de Souza Júnior ${ }^{1}$ (D), \\ João Marcelo Azevedo de Paula Antunes ${ }^{1^{*}}$ (i)
}

\begin{abstract}
Interventricular septal defect (IVSD) is a congenital heart disease characterized by communication or nonclosure of the interventricular septum in the embryonic or postnatal period, causing a failure in the separation between the systemic and pulmonary circulation. The severity of the hemodynamic consequences depends on the extent of the defect and the magnitude of the flow through it. Blood flow commonly occurs from left to right, because systemic vascular resistance is greater than pulmonary resistance. This report describes the echocardiographic findings in a 4-year-old male Poodle treated at the Veterinary Hospital with a history of exercise intolerance, cyanosis and episodes of syncope. On echocardiography, perimembranous IVSD was diagnosed with atrial and right ventricular dilatation, discontinuity of the interventricular septum in the subaortic region measuring approximately $5 \mathrm{~mm}$. In the Doppler evaluation, reverse turbulent flow was evidenced, characterizing shunt from right to left (Eisenmenger syndrome). Despite preserved systolic function, abnormal relaxation was observed. Doppler echocardiography was a fundamental complementary imaging test for the diagnosis of this congenital heart disease since its suspicion is not commonly raised in adult patients. Doppler echocardiography allowed us to identify the defect, define its size and extension, determine the direction of blood flow as well as its hemodynamic consequences.
\end{abstract}

KEYWORDS: Perimembranous; Congenic cardiopatics; Veterinary Cardiology; Echocardiography.

\begin{abstract}
RESUMO: O defeito do septo interventricular (DSIV) é uma cardiopatia congênita caracterizada pela comunicação ou não fechamento do septo interventricular no período embrionário ou pós-natal, causando falha na separação entre a circulação sistêmica e pulmonar. A gravidade das consequências hemodinâmicas depende da extensão do defeito e da magnitude do fluxo através dele. O fluxo sanguíneo comumente ocorre da esquerda para a direita, porque a resistência vascular sistêmica é maior do que a pulmonar. Este relato descreve os achados ecocardiográficos em um Poodle, macho, de 4 anos atendido no Hospital Veterinário com história de intolerância ao exercício, cianose e episódios de síncope. Ao ecocardiograma foi diagnosticado DSIV do tipo perimembranoso com dilatação atrial e ventricular direita, descontinuidade do septo interventricular em região subaórtica medindo aproximadamente $5 \mathrm{~mm}$. $\mathrm{Na}$ avaliaçáo Doppler, evidenciou-se fluxo turbulento reverso, caracterizando shunt da direita para a esquerda (síndrome de Eisenmenger). Apesar da função sistólica preservada, foi observado relaxamento anormal. A ecocardiografia Doppler foi um exame de imagem complementar fundamental para o diagnóstico dessa cardiopatia congênita, uma vez que sua suspeita não é comumente levantada em pacientes adultos. A ecocardiografia Doppler permitiu identificar o defeito, definir seu tamanho e extensão, determinar a direção do fluxo sanguíneo, bem como suas consequências hemodinâmicas.
\end{abstract}

PALAVRAS-CHAVE: Perimembranoso; Cardiopatia Congênita; Cardiologia Veterinária; Ecocardiografia

\section{INTRODUCTION}

Congenital alterations result from morphophysiological irregularities observed at birth due to genetics, environmental factors, or a combination of both. Cardiac malformations can be incompatible with fetal life or allow the individual to survive to adulthood, although with functional impairments (BUSSADORI; PRADELLI, 2015).

Ventricular septal defect (VSD) is considered a frequent congenital heart disease in dogs (OLIVEIRA et al., 
2011), representing $35 \%$ of diagnosed cardiac malformations (HOFFMAN; KAPLAN, 2002).

VSD is characterized by failure of the interventricular septum (IVS) to close during the embryonic or postnatal period (SOUSA FILHO et al., 2015; VOROS et al., 2011). It is classified according to its anatomical location in the septum as perimembranous (or subaortic, which is the most common), supracristal (conoseptal, subarterial, or infundibular), and muscular or posterior (BOMASSI et al., 2015; BUSSADORI; PRADELLI, 2015) .

Regardless of the type, this defect allows blood to flow between the ventricles. The degree and direction of this blood flow is influenced by the size of the defect and the pressure differential between the ventricles, with varying clinical manifestations (MACDONALD, 2006). Animals with small defects can be asymptomatic. Moderate left-to-right shunts mainly generate clinical signs of left congestive heart failure (CHF), such as exercise intolerance, dyspnea, apathy, systolic murmur, and syncope, due to pulmonary edema and compression of the main bronchi by left atrial dilatation. With the development of pulmonary arterial hypertension $(\mathrm{PAH})$, signs of right CHF predominate, such as cyanosis, syncope, convulsion, and other manifestations of hypoxia (DURANTE et al., 2013). The most common direction of flow through the septal defect is from left to right, due to the lower pulmonary compared to systemic vascular resistance (REGINALDO et al., 2015). In cases of stenosis or development of pulmonary hypertension, the shunt flow direction can be reversed; this phenomenon, known as Eisenmenger syndrome, leads to increased severity of clinical signs (BUSSADORI; PRADELLI, 2015).

Several tools can help in the diagnosis of heart disease. However, echocardiography has been the basis for the diagnosis of VSD, as it is a dynamic, noninvasive method capable of identifying, locating, and measuring the septal defect and its hemodynamic repercussions, as well as defining the degree and direction of shunt flow through this passage by means of Doppler sonography (BUSSADORI; PRADELLI, 2015; CASTRO et al., 2009; SOUSA FILHO et al., 2015).

Treatment of a VSD depends on the severity of disease, and echocardiographic findings can guide the choice of optimal therapeutic strategy (pharmacological and/or surgical approach), thus contributing to a better prognosis for the patient (SOUSA FILHO et al., 2015). The aim of the present report was to describe the diagnostic contribution of echocardiography in a case of perimembranous or subaortic VSD in an adult dog with Eisenmenger syndrome.

\section{CASE REPORT}

A 4-year-old, sexually intact Poodle weighing $5.8 \mathrm{Kg}$ was treated at Hospital Veterinary Dix-Huit Rosado Mais da UFERSA
(Federal Rural University of Semi-Arid), located in the city of Mossoró, Rio Grande do Norte, Brazil. The owner reported a history of exercise intolerance, cyanosis, and episodes of syncope. Physical examination showed an active, well-hydrated, well-nourished dog with pale mucous membranes, a respiratory rate of 30 breaths per minute, a body temperature of $37.6^{\circ} \mathrm{C}$, capillary perfusion time of 2 seconds, and regular cardiac rhythm with a moderate systolic murmur. Based on the clinical suspicion of heart disease, an echocardiographic examination was requested.

Two-dimensional M-mode, color, and pulsed Doppler echocardiography was performed with an Ultramedic ${ }^{\circledast}$ Infinit $7 \mathrm{~V}$ system running cardiology software and a sector transducer with a frequency of 5 to $7 \mathrm{MHz}$. After extensive shaving of the cranial chest wall bilaterally, the patient was restrained in right and left lateral recumbency and a thick layer of conductive gel was applied between the skin and the transducer to improve sound transmission and, consequently, image quality.

Echocardiographic examination revealed an approximately 5-mm discontinuity of the perimembranous IVS in the subaortic region (Figure 1).

Doppler evaluation showed turbulent flow in the rightto-left direction (reverse shunt), characterizing Eisenmenger syndrome (Figure 2). Right atrioventricular dilatation was also identified (Figure 3). At the time of examination, the right ventricle measured $0.92 \mathrm{~cm}$ in diastole, and the left-toright ventricle ratio in diastole (LV/VDd) was approximately $1: 1$. During examination and positioning of the animal, possibly due to the VSD, it began to become quite agitated and fatigued, which made it impossible to examine for tricuspid regurgitation or to measure flow velocity to estimate pressures; however, subjective assessment was consistent with right ventricular enlargement and flattening of the IVS towards the left chamber (Figure 3).

Systolic function indices by the Teichholz method were within reference values, although an abnormal relaxation was found ( $\mathrm{E}$ wave smaller than the A wave). Doppler echocardiographic indices are described in table 1.

\section{DISCUSSION}

Taken together, the echocardiographic findings supported the diagnosis of VSD with Eisenmenger syndrome. According to the latest consensus on PAH (REINERO et al., 2020) this case is classified in the $1 \mathrm{~d} 1$ group of congenital hypertension. Although pressure was not estimated in this patient, the consensus statement notes that congenital defects have a high probability of being associated with pulmonary hypertension, findings of right ventricular dilatation, and IVS flattening.

According to Hoffman; Kaplan (2002), 35\% of diagnosed congenital heart defects are classified as VSD. GLEN; BURNS; BLOOMFIEL (2004) reported that 

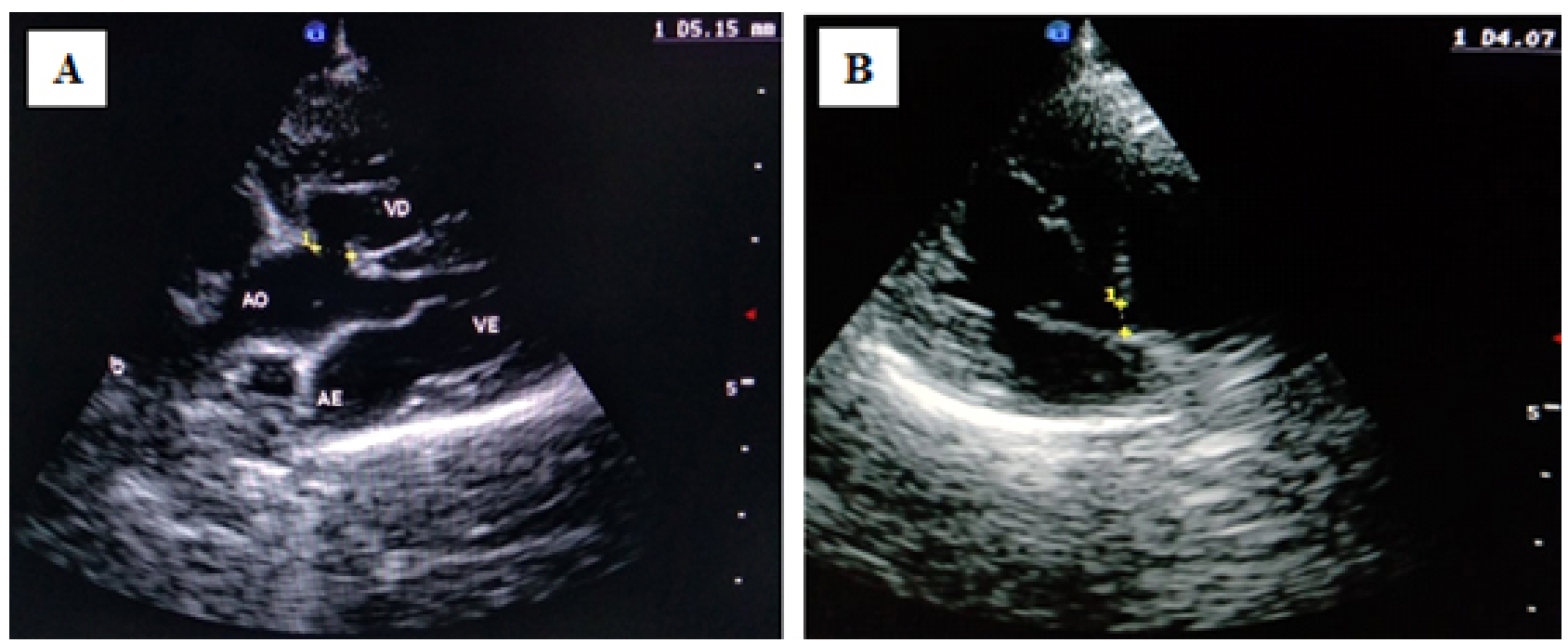

(AO) Aorta; (VD) Right ventricle; (VE) Left ventricle; (AE) Left atrium; (AD) Right atrium; (AE) Left atrium; (VD) Right ventricle; (VE) Left ventricle. Figure 1. Two-dimensional echocardiographic images in the right parasternal window, four-chamber longitudinal section (A) and in the left parasternal window, four-chamber apical section (B), showing discontinuity of the interventricular septum in its cranial aspect, close to the aorta artery, measuring $5.15 \mathrm{~mm}$ (caliper marking in yellow).
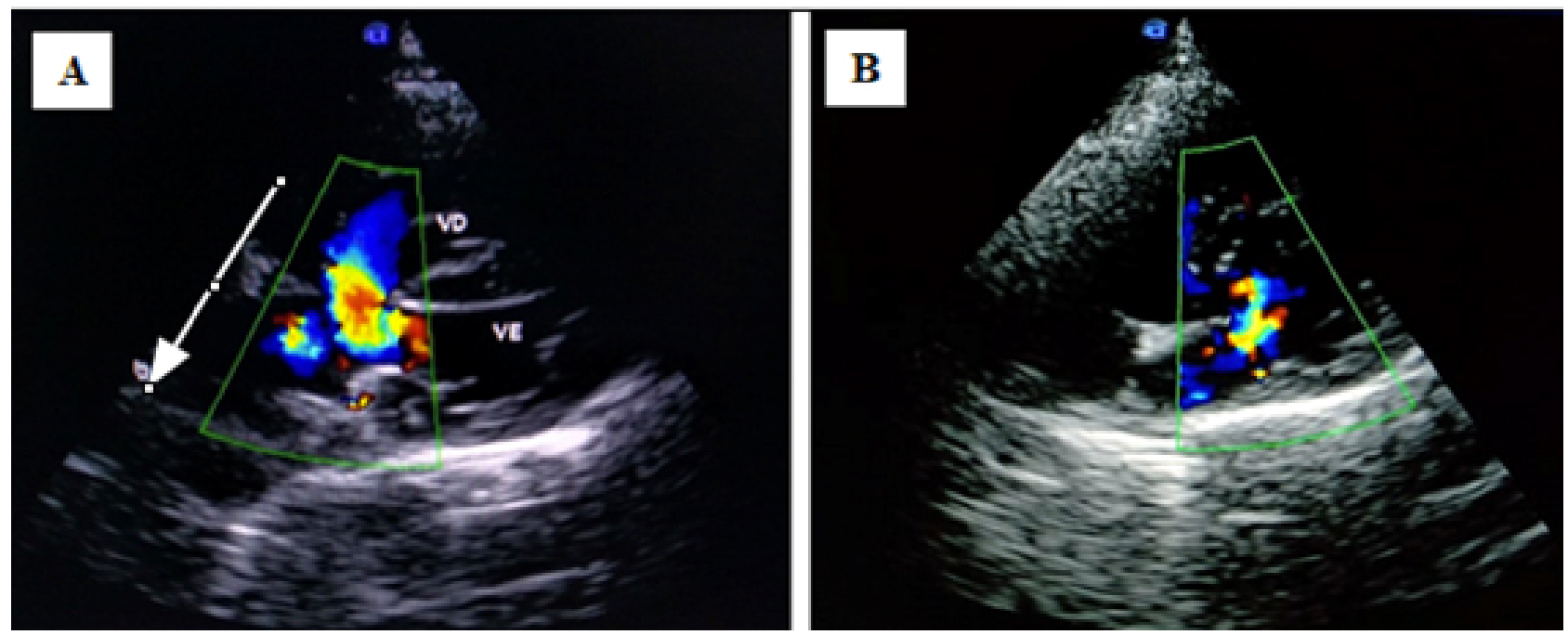

(VD) Right ventricle; (VE) Left ventricle; (VD) Right ventricle; (VE) Left ventricle.

Figure 2. Echocardiographic evaluation with color Doppler in the right parasternal window, four-chamber longitudinal section (A) and in the left parasternal window, apical four-chamber view (B), showing turbulent blue flow (VD) moving away from the transducer through the IVSD with right-to-left direction (reverse shunt) characterizing Eisenmenger syndrome

$76 \%$ of VSD cases are of the perimembranous type, corroborating the type and classification of congenital heart disease diagnosed in this case. A VSD may present alone or concomitantly with other alterations, such as atrial septal defect and patent ductus arteriosus; however, 78\% are isolated (GLEN, BURNS; BLOOMFIEL, 2004), as in the present report.

VSD closure tends to occur within the first two years of life (DURING et al., 2013), and clinical signs are usually evident before one year of age. However, the animal described in this report only developed clinical signs in adulthood. This late clinical presentation may have occurred due to the small size of the defect, compounded by the development of discreet clinical signs that may be difficult for the owner to perceive. As noted by Macdonald (2006), the clinical signs of VSD are variable and dependent on the size of the defect, which may be asymptomatic. In this case, we believe that the animal developed Eisenmenger syndrome because of pulmonary hypertension. Complaints of exercise intolerance, cyanosis, and episodes of syncope in this patient are consistent with the signs reported by Durante et al. (2013).

The use of color flow mapping allowed visualization of flow through the defect. The contribution of color Doppler echocardiography to the diagnosis of VSD has been described by Oyama; Sisson (2001). Shunt flow usually occurs from 

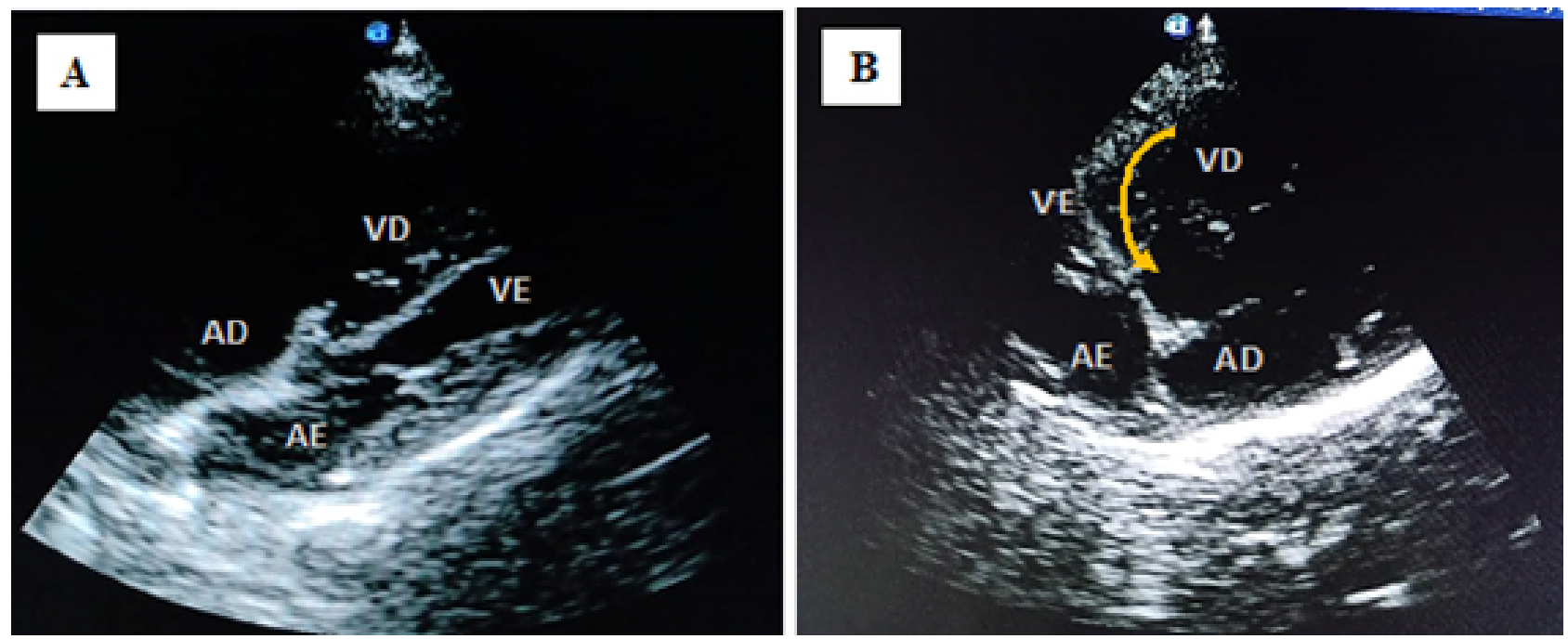

(AD) Right atrium; (AE) Left atrium; (VD) Right ventricle; (VE) Left ventricle; (AD) Right atrium; (AE) Left atrium; (VD) Right ventricle; (VE) Left ventricle. Figure 3. Two-dimensional echocardiographic evaluation in the right parasternal window, four-chamber longitudinal section (A) and in the left parasternal window, four-chamber apical section (B), showing right atrioventricular dilatation and flattening of the SIV projecting to the left (arrow).

Table 1. Quantitative Doppler echocardiographic indices obtained that show preservation of systolic function

\begin{tabular}{l|c} 
LVd & $1,72 \mathrm{~cm}$ \\
\hline LVs & $0,97 \mathrm{~cm}$ \\
\hline LVFWd & $0,64 \mathrm{~cm}$ \\
\hline LVFWs & $1,05 \mathrm{~cm}$ \\
\hline VSd & 0,8 \\
\hline VSs & 1,19 \\
\hline Shortening Fraction & $43 \%$ \\
\hline Ejection Fraction & $78 \%$ \\
\hline Maximal velocity of E wave & $50,8 \mathrm{~m} / \mathrm{s}$ \\
\hline Maximal velocity of A wave & $67,4 \mathrm{~m} / \mathrm{s}$ \\
\hline
\end{tabular}

(LVd) Left ventricular lumen in diastole; (LVs) Lumen of the left ventricle in systole; (LVFWd) Free wall of the left ventricle in diastole; (LVFWs) Free wall of the left ventricle in systole; (VSd) Interventricular septum in diastole; (VSs) Interventricular septum in systole.

left to right, because pulmonary vascular resistance is lower than that of the systemic vasculature, causing left ventricular failure due to volume overload (REGINALDO et al., 2015). In the present report, flow was reversed, probably due to the development of pulmonary hypertension, as, according to Reinero et al. (2020), PAH generates an increase in right ventricular resistance to the point of exceeding the pressure in the left ventricle, creating conditions for a change in the direction of blood flow through the septal defect, a phenomenon known as Eisenmenger syndrome (ZABKA; CAMPBELL; WILSON, 2006).

Echocardiography has been increasingly used for cardiac assessment in routine veterinary practice due to its dynamic, noninvasive nature (CASTRO et al., 2009). It allows identification and sizing of congenital defects, as well as assessment of their hemodynamic repercussions (BULMER, 2011; BUSSADORI; PRADELLI, 2015), providing crucial information to guide management.

Despite the abnormal relaxation found in this patient $(\mathrm{E}>\mathrm{A})$, this isolated parameter was not considered indicative of diastolic dysfunction, as there were no signs of left ventricular hypertrophy, and other values such as isovolumic relaxation time and pulmonary vein parameters were not measured. Systolic function was preserved, in agreement with Madron; Chetboul; Bussadori (2015), who note that despite the defect and the volume overload generated by it, with increased ventricular diameter in diastole, the thickness of the muscle wall remains unchanged, maintaining physiological systolic activity.

In this case, echocardiography was essential to correlate VSD as a precursor of the possible development of PAH, since other differential diagnoses that cause volume overload and stenosing processes, such as other congenital heart diseases, left heart failure, thrombi, and neoplasms, can also lead to PAH (REINERO et al., 2020). The patient in this case was lost to follow-up, and we have no information about subsequent therapy or clinical status. However, it is known that the information about VSD provided by echocardiographic examination allows more satisfactory therapeutic planning and consequent optimization of prognosis (REINERO et. al., 2020).

\section{CONCLUSIONS}

Doppler echocardiography was particularly essential for the diagnosis of VSD in this case because these defects are not commonly suspected in adult animals; other cardiac diseases are more common causes of the observed clinical presentation in this age range. Echocardiography allowed us to identify the defect, define its size, determine the direction of blood flow and assess possible hemodynamic consequences. 


\section{REFERENCES}

BOMASSI, E. et al. Signalment, clinical features, echocardiographic findings, and outcome of dogs and cats with ventricular septal defects: 109 cases (1992-2013). Journal of the American Veterinary Medical Association, v. 247, n. 2, p. 166-175, 2015.

BUSSADORI, C.; PRADELLI, D. Congenital cardiopathies. In: BUSSADORI, C.; PRADELLI, D. Clinical echocardiography of the dog and cat. 1 ed. St. Louis: Elsevier Masson, 2015. p.303-305.

CASTRO, M. G. et al. Estudo retrospectivo ecodopplercardiográfico das principais cardiopatias diagnosticadas em cães. Arquivo Brasileiro de Medicina Veterinária e Zootecnia, v. 61, n. 5, p. 1238-1241, 2009.

DURANTE, H.F. et al. Defeito anatômico no septo interventricular em cão - relato de caso. Acta Veterinaria Brasilica, v. 7, supl. 1, 2013.

GLEN, S.; BURNS, J.; BLOOMFIEL, P. Prevalence and development of additional myocarditis be normal in 1448 patients with congenital ventricular septal defects. Heart, v. 90, n. 1l, p. 1321-1325, 2004.

HOFFMAN, J. I. E.; KAPLAN, S. The incidence of congenital heart disease. Journal of the American College of Cardiology, v. 39, n. 12, p.1890-900, 2002.

MACDONALD, K.A. Congenital heart diseases of puppies and kittens. Veterinary Clinics of North America: Small Animals Practice, v. 36, p. 503-531, 2006.

MADRON, E.; CHETBOUL, V.; BUSSADORI, C. In: BUSSADORI, C.; PRADELLI, D. Clinical echocardiography of the dog and cat. I ed. Elsevier Health Sciences, 2015.
OLIVEIRA, P. et al. Retrospective review of congenital heart disease in 976 dogs. Journal of Veterinary Internal Medicine, v. 25, п. 3, p. 477-483, 2011.

OYAMA, M. A.; SISSON, D. D. Evaluation of Canine Congenital Heart Disease Using an Echocardiographic Algorithm. Journal of the American Animal Hospital Association, v.37, n. 6, p. 519-535, 2001.

REINERO, C.; VISSER, L.C.; KELLIHAN, H.B.; MASSEAU, I.; ROZANSKI, E.; CLERCX, C.; WILLIAMS, K.; ABBOTT, J.; BORGARELLI, B.; SCANSEN, B.A.; ACVIM consensus statement guidelines for the diagnosis, classification, treatment, and monitoring of pulmonary hypertension in dogs. Journal of Veterinary Internal Medicine, v.34, p.549-573, 2020.

REGINALDO, P. S. F. et al. Defeito do septo ventricular em gato. Revista Portuguesa de Ciências Veterinárias, v.110, n.595, p.140-143, 2015

SOUSA FILHO, R. P.; MATOS, G. O.; SOUSA, F. C.; SAMPAIO, K. O.; CUNHA, M. G. M. C. M..; BARBOSA, P. S. F. Defeito do septo ventricular em gato. Revista Portuguesa de Ciências Veterinárias, ก. 110, p. 140-143, 2015.

VOROS, K. et al. Ventricular septal defect with aortic valve insufficiency in a New Zealand White rabbit. Journal of the American Animal Hospital Association, v.47, n.4, p.42-49, 2011.

ZABKA, T. S.; CAMPBELL, F. E.; WILSON, D. W. Pulmonary Arteriopathy and Idiopathic Pulmonary Arterial Hypertension in Six Dogs. Veterinary Pathology, v.43, n.4, p.510-522, 2006. 